\title{
Till nytta eller onytta: Argument rörande allmänna ämnen $i$ ungas yrkesutbildning $i$ efterkrigstidens Sverige
}

\begin{abstract}
Keywords
Vocational education and training, general subjects, curriculum reform, educational politics, upper secondary education
\end{abstract}

Yrkesutbildning, allmänna ämnen, utbildningsreformer, utbildningspolitik, gymnasieskola

\author{
KRISTINA LEDMAN *
}

To cite this article

Kristina Ledman, "Till nytta eller onytta: Argument rörande allmänna ämnen i ungas yrkesutbildning i efterkrigstidens Sverige,” Nordic Journal of Educational History 1, no. 1 (2014), pp. 21-43.

\section{Introduktion}

Den svenska gymnasieskolan fick sin nuvarande utformning genom 2011 års gymnasiereform (Gy 11). Reformen står enligt flera forskare för ett avsteg från den linje som präglat gymnasieskolans utveckling i närmare femtio år, dels därför att den innebär att en tidigare strävan att minska skillnaderna mellan olika studieinriktningar frångås, dels genom att gymnasieskolans demokratiska uppgift tonats ned och att skolans uppdrag istället mer direkt ställts i relation till arbetsmarknadens behov. ${ }^{1}$

\footnotetext{
* Doctoral Candidate of History and Education, Department of Historical, Philosophical and Religious Studies, Umeå University. Email: kristina.ledman@historia.umu.se.

${ }^{1}$ Emma Arneback och Andreas Bergh, ”Den paketerade valfriheten: Om Framtidsvägen för den svenska gymnasieskolan," Nordisk Pedagogik 30 (2010); Ylva Bergström och Ninni Wahlström, "En reformerad gymnasieskola: Med vilka ambitioner?," Utbildning \& Demokrati 17 (2008); Sara Carlbaum, Blir du anställningsbar lille/a vän? Diskursiva konstruktioner av framtida medborgare i gymnasiereformer 1971-2011
} 
Genom reformen 2011 stärktes - i linje med detta omdirigerade uppdrag - åtskillnaden mellan yrkesinriktade och studieförberedande program. För yrkesprogrammen innebar detta mer konkret att tiden för yrkesutbildning fick större utrymme i läroplanen på bekostnad av allmänna ämnen.

En av de centrala aspekterna i förändringen av den gymnasiala yrkesutbildningen är just själva omfattningen av de allmänna ämnena. ${ }^{2}$ De allmänna ämnenas plats $\mathrm{i}$ läroplanerna för yrkesinriktade utbildningar för unga har ökat successivt genom efterkrigstidens utbildningsreformer, men 2011 skedde alltså ett brott. Detta brott väcker frågan om vilken funktion de allmänna ämnena historiskt sett har tillskrivits i relation till elever på yrkesinriktade program, det vill säga till den grupp ungdomar i utbildningssystemet som kan sägas stå närmast ett utträde på arbetsmarknaden.

I den här artikeln ställs just frågan om hur ökning och minskning av andelen allmänna ämnen har motiverats i de politiska dokument som legat till grund för efterkrigstidens reformarbete gällande gymnasieskolan. Genom att analysera retoriken kring de allmänna ämnenas funktioner är syftet att förbättra förståelsen av de utbildningspolitiska föreställningar och ställningstaganden som har legat till grund för dessa ämnens inträde i, och förändrade utrymme inom, yrkesutbildning för unga. Vilka problem har de allmänna ämnena ansetts lösa inom yrkesutbildningen och vilka olika funktioner har de tillskrivits? Ambitionen i analysen är att klargöra hur retoriken har förändrats över tid samt att visa vilka förskjutningar, kontinuiteter och brott som kan urskiljas under perioden. Detta görs utifrån begreppen kvalifikation, socialisation och subjektifiering, såsom de formuleras av Gert Biesta (se vidare nedan). ${ }^{3}$

\section{Yrkesutbildning och allmänna ämnen: Definitioner och analytiska nedslag}

När jag här talar om yrkesutbildning för unga avser jag huvudfåran inom ungas institutionaliserade yrkesutbildning, det vill säga det som idag kallas yrkesprogram, tidigare yrkesförberedande program, i linjegymnasiet yrkeslinjer och innan dess yrkesutbildning organiserad i skolform. ${ }^{4}$ Lärlingsutbildning har historiskt sett haft en svag ställning i Sverige och utgör fortfarande ett tämligen begränsat stråk av de gymnasiala utbildningsvägarna. Därför har lärlingsutbildningen inte beaktats i studien. 5

(Umeå: Umeå universitet, 2012); Lisbeth Lundahl "Skilda framtidsvägar: Perspektiv på det tidigare 200o-talets gymnasiereform," Utbildning \& Demokrati 17 (2008); Lisbeth Lundahl et al.,"Setting Things Right? Swedish Upper Secondary School Reform in a 40-Year Perspective," European Journal of Education, 45 (2010); Mattias Nylund, Yrkesutbildning, klass och kunskap: En studie om sociala och politiska implikationer av innehållets organisering i yrkesorienterad utbildning med fokus på 2011 års reform (Örebro: Orebro universitet, 2013).

2 Jan Berggren har uppmärksammat detta i ”En gemensam resa eller skilda resor: Talet om kärnämnen i gymnasieskolan 1990- 2009," Utbildning\& Demokrati 21 (2012).

3 Gert Biesta, "Good Education in an Age of Measurement: On the Need to Reconnect with the Question of Purpose in Education," Educational Assessment, Evaluation and Accountability 21 (2009); Gert Biesta, God utbildning i mätningens tidevarv (Stockholm: Liber, 2011).

4 I dagens gymnasieskola finns exempelvis Bygg- och anläggningsprogrammet, Restaurang- och livsmedelsprogrammet och Vård- och omsorgsprogrammet samt Fordons och transportprogrammet. De ersatte de tidigare yrkesförberedande programmen Bygg, Hotell- och restaurang, Livsmedel, Omvårdnad samt Fordon. I linjegymnasiet motsvarades dessa i viss mån av de tvååriga yrkeslinjerna Bygg- och anläggningsteknisk, Livsmedelsteknisk, Vårdlinje samt Fordonsteknisk. Fram till 1990-talet fanns även många specialutbildningar i varierande längd.

5 I normalfallet följer lärlingsutbildningen samma examensmål och har samma programstruktur som motsvarande yrkesprogram. Vidare finns introduktionsprogrammen, varav en inriktning mot yrkesintroduktion, för de elever som inte har behörighet för gymnasieskolans program. Läsåret 2012/13 var andelen förstahandssökande till ett högskoleförberedande program 57 procent och till ett yrkesprogram 37 procent. Andelen 
I den studie som artikeln bygger på har jag undersökt de utbildningspolitiska texternas formuleringar rörande de ämnesinslag i yrkesutbildningen som inte direkt associeras med det framtida yrket. I artikeln benämns dessa ämnesinlag "allmänna ämnen". När det gäller yrkesutbildning får dessa "allmänna ämnen" ofta en problematisk ställning, eftersom de inte är specifikt riktade mot en förberedelse för ett yrke eller är karakteristiska för utbildningens generella inriktning. ${ }^{6}$

Tyngdpunkten i undersökningen sträcker sig från ett beslut 1968 om att sammanföra yrkesskolan med gymnasiet och fackskolan, till 2009 års beslut om formerna för dagens gymnasieskola vilka stadgades i Gy 11. Men eftersom 1968 års beslut föregicks av ett längre reformarbete rörande det obligatoriska och frivilliga skolväsendet har även ett betänkande från Skolkommissionen från 1948 samt ett betänkande från 1952 års yrkesutbildningssakkunniga tagits med i undersökningen. Utvecklingen av yrkesutbildningen har under efterkrigstiden genomgått flera förändringar. Redan i anslutning till kriget ökade intresset för yrkesutbildning och för en utbyggnad av densamma, men det var dock först 1968 som ett beslut om inlemmande av yrkesskolan i gymnasieskolan fattades. 1991 beslutades om en förlängning av den yrkesförberedande utbildningen till treåriga gymnasieprogram, vilka genom 2009 års beslut återfick en högre grad av specialisering. Besluten 1968, 1991 och 2009 har i analysen av materialet framträtt som tydliga brottpunkter i utvecklingen och därför ägnas de särskild uppmärksamhet i artikeln.

\section{Yrkesutbildningens bakgrund och organisering}

Fram till och med 1940-talet var intresset för yrkesutbildningens organisation, dess roll i samhället och i utbildningssystemet begränsat.7 Parallellt med reformarbetet med den obligatoriska grundskolan ökade dock successivt intresset för yrkesutbildningen, exempelvis för frågor om när den skulle påbörjas och under vilka former den skulle bedrivas. Grundskolebeslutet 1962 innebar att differentieringen i mer studieförberedande och yrkesförberedande linjer skulle ske först i årskurs 9 där linje y skulle ge eleverna yrkesförberedande utbildning. Linjeindelningen, och därmed den direkt yrkesförberedande undervisningen inom ramen för grundskolan, togs emellertid bort i 1969 års läroplan för grundskolan (Lgr 69) när yrkesutbildningen flyttades högre upp

som sökte yrkesprogram i första hand minskade med två procentenheter. 6 procent av sökte något av introduktionsprogrammen i första hand. Skolverket, "Sökande och antagna i gymnasieskolan läsåret 2012/13," PM, Dnr 71-2013:28, http://www.skolverket.se/publikationer?id=2992 (2014-01-15).

6 Resonemanget om allmänna ämnen kan förstås mot bakgrund av allmänbildningsbegreppet, som dels kan härledas ur upplysningstidens liberala idé om en allmän borgerlig bildning, det vill säga allmän i bemärkelsen att den omfattar alla människor, dels ur nyhumanismen och det klassiska bildningsbegreppet där allmän avser ett urval från t.ex. historieämnet. Nationalencyklopedin föreslår definitionen: "beteckning för en bred kännedom om allmängiltiga ämnen, till skillnad från specialiserad fackkunskap". En annan definition är "bildning för bildningens och den personliga utvecklingens egen skull, utan tanke på dess nytta; 'allmän' i motsats till bunden till en viss verksamhet eller ett visst yrke”. Nationalencyklopedin, http://www.ne.se/lang/allm\%C $3 \%$ A4nbildning (2014-01-16); Henry Egidius, Termlexikon i pedagogik: Skola och utbildning (Lund: Studentlitteratur, 2006).

7 Sixten Marklund, Skolsverige 1950-1975 (D. 1): 1950 års reformbeslut (Stockholm: Liber/Utbildningsförl., 1980), 32. År 1918 kom ett riksdagsbeslut om inrättandet av lärlingsskolor och yrkesskolor. Yrkesundervisningen byggdes också ut med handelsskolor och hushållskolor och som ett svar på den höga arbetslösheten inrättades verkstadsskolor. Få genomgick emellertid någon yrkesutbildning, och i praktiken följde den i stor utsträckning en lärlingsmodell. Den tidiga utbyggnaden av yrkesskoleväsendet växte fram med en begränsad statlig styrning och resultatet var ett system med stora lokala skillnader och en stor andel privata utbildningsproducenter. Gunnar Richardson, Svensk utbildningshistoria: Skola och samhälle förr och nu (Lund: Studentlitteratur, 2004), 115-16; Jonas Olofsson, "Yrkesutbildning och utbildningspolitik: En inledande översikt," i Yrkesutbildningen i går och i dag, red. Jonas Olofsson och Ingela Schånberg (Lund: Studentlitteratur, 2000), 24-25. 
i åldrarna. ${ }^{8}$ I och med att behovet av yrkesutbildning ökade under de första decennierna efter andra världskriget byggdes också yrkesskolan ut kraftigt under 1950- och 1960-talen. 1968 lade den socialdemokratiska regeringen fram ett förslag om den första strukturella reformen av yrkesutbildningen sedan 1918. Reformen innebar att yrkesskolan tillsammans med gymnasiet och fackskolan ingick i en sammanhållen frivillig skolform, gymnasieskolan, som skulle erbjuda alla ungdomar en minst tvåårig utbildning efter den nioåriga grundskolan. Hösten 1971 realiserades reformen och den gymnasiala yrkesutbildningen fick formen av yrkesförberedande, främst tvååriga, linjer, där yrkesämnena kraftigt minskades jämfört med tidigare och där de allmänna ämnena ökade. 9 Som ett svar på en kritik mot att de tvååriga yrkeslinjerna inte var tillräckligt anpassade till det moderna arbetslivets behov tillsatte den socialdemokratiska regeringen under Olof Palme en arbetsgrupp för översyn av den gymnasiala yrkesutbildningen (ÖGY) 1984. Gruppens betänkande utgjorde en grund för en försöksverksamhet, liksom för 1991 års beslut om treåriga gymnasiala yrkesförberedande program. Under 1990-talet följde utredningar om en ytterligare utveckling av gymnasieskolan och 2004 lade den då sittande socialdemokratiska regeringen fram ett förslag om en reform som skulle genomföras 2007. Efter valet 2006, då Socialdemokraterna tillsammans med stödpartierna Vänsterpartiet och Miljöpartiet förlorade regeringsmakten till en borgerlig allians bestående av Moderaterna, Centerpartiet, Folkpartiet och Kristdemokraterna, beslutade den nytillträdda borgerliga regeringen att riva upp reformen. Istället tillsattes en utredning vars betänkande utmynnade i beslutet 2009 om dagens gymnasieskola med en tydligare uppdelning mellan yrkesoch studieförberedande program.

\section{Tidigare forskning och studiens vetenskapliga bidrag}

Yrkesutbildningens historia är fortfarande relativt sparsamt utforskad i en svensk kontext. ${ }^{10}$ Jonas Olofssons arbeten om svensk yrkesutbildning är centrala inom området, liksom bidragen i antologin Yrkesutbildning igår och idag. ${ }^{11}$ Central är också Lisbeth Lundahls studie av LO:s och SAF:s utbildningspolitik under efterkrigstiden, en studie som, tillsammans med bidrag från Anders Nilsson och Lars Pettersson, utgör exempel på forskning som rör arbetsmarknadens parter och deras involvering i yrkesutbildning. ${ }^{12}$ Lennart Nilssons avhandling från 1981 ger en detaljerad översikt av yrkesutbildningens framväxt fram till 1980-talet. ${ }^{13}$ Ett nytt bidrag rörande yrkesutbildning är Mattias Nylunds avhandling Yrkesutbildning, klass och kunskap, som behandlar sociala och politiska konsekvenser av yrkesutbildningens organisation och

\footnotetext{
8 Sixten Marklund, Skolsverige 1950-1975 (D. 2): Försöksverksamheten (Stockholm: Liber/Utbildningsförl., 1982), 221-24, 240; Sixten Marklund, Skolsverige 1950-1975 (D. 4): Differentieringsfrågan (Stockholm: Liber/Utbildningsförl., 1985), 205-6; Richardson (2004), 124.

9 Jonas Olofsson, Svensk yrkesutbildning: Vägval i internationell belysning (Stockholm: SNS förlag, 2005), 111-14; Richardson (2004), 134; SOU 1986:2, Arbetsgruppen för översyn av den gymnasiala yrkesutbildningen, En tre $\neg$ årig yrkesutbildning: Betänkande, 15.

10 Jonas Olofsson, Krisen i skolan: Utbildning i politiken och i praktiken (Umeå: Boréa, 2010), 14.

11 Olofsson och Schånberg (red.), (2000); Olofsson (2005).

12 Lisbeth Lundahl, Efter svensk modell: LO, SAF och utbildningspolitiken 1944-9o (Umeå: Boréa, 1997); Anders Nilsson, Visions and Labour Demand: The Planning of Vocational Education for the Swedish Manufacturing Industry 1950-1993 (Lund: Lund Papers in Economic History nr. 39, 1994); Lars Pettersson, "Yrkesutbildning för tillväxt," Arbetsmarknad \& Arbetsliv (1997), 1.

13 Lennart Nilsson, Yrkesutbildning i nutidshistoriskt perspektiv: Yrkesutbildningens utveckling från skråväsendets upphörande 1846 till 1980-talet samt tankar om framtida inriktning (Göteborg: Acta Universitatis Gothoburgensis, 1981).
} 
innehåll. ${ }^{14}$ I en analys av strukturreformer mellan 1971 och 2011 uppmärksammar han bland annat att kunskapsfrågorna varit marginaliserade i samtliga reformer och att innehållet istället har formulerats i relation till externa behov. Vidare har det skett en förskjutning från specifika kunskaper (1971) till egenskaper som flexibilitet (1990) och anställningsbarhet (2011). ${ }^{15}$ Den mer allmänna utvecklingen av det svenska utbildningsväsendet har studerats av bland annat Gunnar Richardson och Sixten Marklund. ${ }^{16}$ Dessa bidrag berör indirekt förändringar av andelen allmänna ämnen inom den yrkesinriktade gymnasieutbildningen, men undersöker inte specifikt de motiv som legat till grund för förändringarna. Det gör däremot Tomas Englunds analys av medborgarfostran. Han menar att samhällskunskapsämnets expansion och historieämnets reduktion efter andra världskriget kan förklaras genom att samhällsämnet representerade en samhällsorienteringsmodell som svarade mot den "vetenskapligt rationella utbildningskonception" som dominerade efterkrigstidens första decennier. ${ }^{17}$

Gy 11 beskrivs i flertalet studier som ett avsteg från den tidigare trenden i gymnasiets utveckling. Emma Arneback och Andreas Berg hävdar bland annat att det demokratiska utbildningsmålet tonats ned och att det framträtt en mer konservativ syn på gymnasieskolans uppdrag. ${ }^{18}$ På samma sätt finner Ylva Bergström och Ninni Wahlström att de medborgerliga aspekterna av gymnasieskolans uppdrag försvagades $\mathrm{i}$ utredningen. ${ }^{19}$ Lisbeth Lundahl, vars studie omfattar ett längre tidsperspektiv, klargör hur en långsiktig trend av integrering av gymnasiets olika inriktningar bröts med förslaget om Gy 11. ${ }^{20}$ Sara Carlbaum visar i sin avhandling, som behandlar konstruktionen av medborgare i utbildningspolitiska dokument, att talet om demokrati, likvärdighet och multikultur tystnade perioden efter 2006, och att gymnasieskolans utbildningsuppdrag därefter istället främst riktats mot arbetsmarknaden och mot målet att utbilda anställningsbara medborgare. ${ }^{21}$ Jan Berggrens studie om kärnämnen i gymnasieskolan mellan 1990 och 2009, som baseras på delvis samma källmaterial som föreliggande studie, uppmärksammar hur talet om kärnämnen under perioden successivt förskjutits. I början av 1990-talet åberopades ett föränderligt samhälle och en kunskapsekonomi i relation till människan som flexibel arbetskraft som motiv för kärnämnena. Retoriken försköts efterhand till ett tal om en anpassning av undervisningen i förhållande till högre utbildning och arbetsmarknad, för att slutligen utmynna i förslag om en skarpare uppdelning mellan högskoleförberedande program och yrkesprogram i de gymnasiegemensamma ämnena. ${ }^{22}$

De icke direkt yrkesförberedande ämnenas ställning inom yrkesutbildningen är dock ett forskningsområde som endast ägnats ett begränsat intresse i tidigare vetenskapliga arbeten. Föreliggande studie syftar därför till att ge ett kunskapstillskott på detta område. I relation till tidigare studier vidgar den både tidsperspektivet och

\footnotetext{
14 Nylund (2013).

15 Nylund (2013).

${ }^{16}$ Marklund (1980); Marklund (1982); Richardson (2004).

17 Tomas Englund, Läroplanens och skolkunskapens politiska dimension (Göteborg: Daidalos, 2005).

18 Arneback och Berg (2010).

19 Bergström och Wahlström (2008).

${ }^{20}$ Lundahl (2008).

21 Carlbaum (2012).

22 Berggren (2012).
} 
fokuserar mer preciserat de allmänna ämnenas avsedda funktioner inom yrkesutbildningen.

\section{Teoretiska ansatser, källor, metod och avgränsningar}

Ett grundläggande uppdrag för utbildningssystemet och skolan är att förmedla kunskaper och färdigheter som ska förbereda barn och ungdomar för deras framtid i samhället. Framtiden råder det emellertid alltid en osäkerhet kring och uppfattningarna om vilka kunskaper och färdigheter som är mest angelägna är centrala ideologiska och politiska frågor. I diskussionerna om utbildningens uppdrag föreslår Biesta att vi utgår från tre skilda, men samtidigt relaterade, funktioner: kvalificering, socialisation och subjektifiering. Eftersom dessa tre oftast finns samtidigt närvarande, bör uppmärksamheten riktas mot den relativa kompositionen av funktionerna. Kvalificeringsfunktionen handlar om att förse elever/individer med kunskaper, färdigheter och förståelse som tillåter dem att "göra någonting”. Denna funktion har stark anknytning till ekonomiska argument. Kvalificering handlar dock också om den kunskap och de kompetenser unga behöver för medborgarskap och för att fungera i samhället. Socialisation handlar enligt Biesta om hur vi blir en del av sociala, kulturella och politiska ordningar, och denna utbildningsfunktion har stor betydelse för att reproducera ett samhälles kultur och traditioner. Subjektifiering kan bäst förstås i motsats till socialisation. Funktionen åsyftar en process där människan utvecklas till en autonom individ med handlingsutrymme. I processen blir människan ett självständigt subjekt. ${ }^{23}$

Hur förhåller sig då kvalificering, socialisation och subjektifiering till andra teoretiska modeller över utbildningsfunktioner? Englund har analyserat medborgarfostran i den svenska skolan utifrån spänningsförhållandet mellan utbildningens funktioner, dels som socialt integrerande i ett rådande ekonomiskt och politiskt system, dels som utgörande potentiella krafter för social förändring av samhällsordningen och av dominerande gruppers inflytande och makt över resurser. ${ }^{24}$ Kopplat till Biestas förklaring av begreppen socialisation och subjektifiering kan detta förstås som att socialisation har ett större utrymme än subjektifiering i den första, socialt integrerande, funktionen och att motsatt förhållande råder i den senare. Ett annat sätt att urskilja utbildningsmål är att utgå från en grundläggande analytisk uppdelning mellan en ekonomisk och en social funktion. Lundahl menar exempelvis att en av aspekterna att beakta vid en jämförelse mellan olika gymnasiereformer är hur betoningen på ekonomiska respektive sociala funktioner hos utbildningen förändras. ${ }^{25}$ Det är dessa funktioner som bland annat Nylund tar fasta på i sin analys av "yrkesutbildning” och "allmänbildning" i utredningen inför 2011 års gymnasiereform. Den förstnämnda syftar till att stärka och vidareutveckla ett demokratiskt och jämlikt samhälle, medan den andra funktionen är förknippad med att effektivisera samhällets produktion och dess ekonomiska tillväxt. ${ }^{26}$

\footnotetext{
23 Biesta (2009), 39-41; Biesta (2011), 19-21.

24 Englund (2005), 24-26.

25 Lundahl (2008), 31-32. Samma resonemang om utbildningens ekonomiska respektive sociala funktion på en aktörs respektive samhällsnivå används av Lisbeth Lundahl et al. (2010).

26 Mattias Nylund, "Framtidsvägen: Vägen till vilken framtid för eleverna i gymnasieskolans yrkesprogram?," Pedagogisk forskning i Sverige 15 (2010), 36-38. För bakgrunden till det teoretiska resonemanget se: Wilfred Carr och Anthony Hartnett, Education and the Struggle for Democracy: The Politics of Educational Ideas (Buckingham: Open University Press, 1996).
} 
Biesta skriver fram funktionerna kvalificering, socialisation och subjektifiering som ett ramverk för diskussionen kring utbildningens syfte och mål. ${ }^{27}$ Genom att använda funktionerna i analysen vill jag ytterligare precisera hur man formulerat de allmänna ämnenas syfte och mål vid olika tidpunkter och därigenom bidra till att förbättra underlaget för samtidens diskussioner kring dessa ämnens roll i gymnasial yrkesutbildning.

Studien baseras på utbildningspolitiska texter i form av utredningar och propositioner som författats under perioden 1948 till 2009. Den huvudsakliga betoningen ligger dock på 1960-talet och framåt. Urvalet består av elva texter. ${ }^{28}$ Undersökningsperiodens början motiveras av att det var skolkommissionens arbete som inledde perioden av reformer gällande det obligatoriska och frivilliga skolväsendet. Införandet av yrkesutbildning inom ramen för en gymnasial utbildning 1971 kan kort sagt inte förstås separat från tidens omorganisering av den obligatoriska skolan. Slutpunkten motiveras av att riksdagen antog propositionen om en ny gymnasieskola 2009. Texterna bör vidare förstås som en form av politiska kompromissprodukter. De förslag, idéer, tankar och argument som läggs fram i en proposition är vad en regering förväntar sig kunna få stöd för från en riksdagsmajoritet. Ett betänkande är en produkt av ett arbete som genomförts av en kommitté, en kommission eller en särskild utredare som tillsatts av regeringen. Regeringen definierar också kommitténs uppdrag genom kommittédirektiv och tilldelning av resurser. Under utredningsarbetet fungerar dock kommittén som en självständig myndighet. ${ }^{29}$

I dessa utbildningspolitiska texter framträder en bild av normalitet - eller common sense vid en viss tidpunkt - vilket gör dem lämpliga att använda som underlag i en studie som vill klarlägga hur logiken kring organiseringen av allmänna ämnen i läroplanen förändrats över tid: Vilka funktioner har de allmänna ämnena tillskrivits, vilka problem har de ansetts lösa för individer och vilken allmän samhällsutveckling har de avsetts stödja? Det är dock viktigt att poängtera att konkurrerande synsätt och intressen som existerat parallellt med att dessa utredningar och remisser författades inte framträder i texterna. Analysen begränsas följaktligen till ovan nämnda texter medan material från aktörer som andra politiska partier eller arbetsmarknadens parter, vilka hade kunnat göra konfliktdimensioner tydligare, inte har ingått i undersökningen.

Under den undersökta perioden har ämnen både tillkommit och försvunnit i gymnasiala yrkesutbildningar. Det gäller exempelvis naturkunskap och arbetslivsorientering, som infördes respektive försvann i samband med 1990-talets reform. Även de

\footnotetext{
27 Biesta (2009); Biesta (2011).

28 SOU 1948:27, 1946 års skolkommissions betänkande med förslag till riktlinjer för det svenska skolväsendets utveckling; SOU 1954:11, Yrkesutbildningen: Betänkande; SOU 1961:30, 1957 års skolberedning. 6, Grundskolan: Betänkande; SOU 1966:3, Yrkesutbildningsberedningen. 1, Yrkesutbildningen; Prop. 1968:140 (Angående riktlinjerna för det fria skolväsendet); SOU 1986:2; Prop. 1987/88:102 (Om utveckling av yrkesutbildningen i gymnasieskolan); Prop. 1990/91:85 (Växa med kunskaper: Om gymnasieskolan och vuxenutbildningen); Prop. 1997/98:169 (Gymnasieskola i utveckling: Kvalitet och likvärdighet); Prop. 2003/04:140 (Kunskap och kvalitet: Elva steg för utvecklingen av gymnasieskolan); Prop. 2008/o9:199 (Högre krav och kvalitet $i$ den nya gymnasieskolan). I de fall då endast propositionerna varit föremål för analys har motivet varit att propositionernas sammanfattande form ansetts som tillräcklig för att möjliggöra en analys av argumentationen kring de allmänna ämnenas plats i läroplanen.

29 Kommittéväsendet har förändrats under perioden som undersöks, på så sätt att kommittéerna under de senaste decennierna i allt högre grad har kommit att få formen av enmansutredningar (jämfört med de tidigare, betydligt bredare utredningarna).
} 
ämnen som till namnet funnits närvarande under större delen av undersökningsperioden har förändrats både till form och innehåll. Det gör att det inte är fullt ut jämförbara storheter som behandlas i denna studie. Att närmare förstå kunskapsmålen för specifika ämnen vid skilda tidpunkter skulle kräva en djupare undersökning av hur respektive ämne formulerats i de olika läroplanerna, men detta är något som inte ryms inom ramen för föreliggande studie.

Analysen av källmaterialet har genomförts i olika steg. En första analys avsåg att identifiera och urskilja förskjutningar, kontinuiteter och brott i retoriken under den aktuella tidsperioden. I mitt arbete med källmaterialet har jag därefter tillämpat en form av tematisk innehållsanalys, på två skilda nivåer. Jag har identifierat de delar av texterna som refererar till betydelsen av allmänna ämnen inom ramen för yrkesutbildning. Genom närläsning av hur allmänna ämnen motiveras i texterna har jag successivt organiserat talet i teman som kan sägas representera tre aspekter av samhällsutvecklingen: demokrati för samhälle och individ, internationalisering och mångkultur samt allmänna ämnen för arbetsliv och ekonomisk tillväxt. Dessa teman är självfallet inte givna, utan ska förstås som kategorier som jag genererat ur empirin med stöd i den grundläggande analytiska uppdelningen mellan utbildningens ekonomiska och sociala funktion som beskrivits ovan. Inom dessa tre övergripande teman har jag därefter genomfört en mer konkret analys av hur de allmänna ämnenas funktion i termer av kvalificering, socialisation och subjektifiering - formulerats i texterna.

\section{Allmänna ämnen i yrkesutbildningen: Brott, argument och aspekter av samhällsutveckling}

De allmänna ämnena ökade som nämnts successivt fram till 2009 och i analysen har tre brott i denna utveckling framträtt. ${ }^{30}$ Ett första brott skedde i samband med införandet av allmänna ämnen i den tidigare yrkesskolan i och med reformen för det frivilliga skolväsendet som presenterades för riksdagen av utbildningsminister Olof Palme 1968. Genom denna reform ökade andelen allmänna ämnen på bekostnad av inslagen av yrkesteknisk utbildning. Ett andra brott markerades genom införandet av den gemensamma kärna av allmänna ämnen i alla gymnasieprogram, som gjordes i enlighet med den socialdemokratiska regeringens förslag om en gymnasiereform 1991. Då gavs ämnena engelska, matematik, estetisk verksamhet, religionskunskap, samhällskunskap och naturkunskap en plats bland de allmänna ämnen som skulle ingå i alla utbildningar, samtidigt som den förberedande yrkesutbildningen på gymnasial nivå förlängdes med ett år. ${ }^{31}$ Det tredje brottet inträffade när den borgerliga regeringen lade fram en proposition om en ny gymnasieskola 2009, där en minskning av tiden för de allmänna ämnena och en återgång till åtskilda kurser för yrkesprogrammen och de studieförberedande programmen lanserades. I samband med detta gjordes historieämnet obligatoriskt. ${ }^{2}$ Svenska, idrott och inslag av samhällsorientering är annars den kärna av allmänna ämnen som under hela perioden betraktats som prioriterad.

\footnotetext{
$3^{0}$ En sammanställning av de allmänna ämnena vid olika tidpunkter redovisas i bilaga 1 och bilaga 2.

31 Den socialdemokratiska regeringens proposition 2003/04:140 med förslaget om att ytterligare utöka de obligatoriska allmänna ämnena med historieämnet realiserades inte i den planerade reformen 2007.

32 Den allmänna behörigheten för högskolan var något som i ett nordiskt sammanhang utmärkte Sverige och Finland. Jonas Olofsson och Eskil Wadensjö, Ungdomar, utbildning och arbetsmarknad i Norden: Lika men ändå olika (Stockholm: Forskningsrådet för arbetsliv och socialvetenskap [FAS], 2007), 42. Efter ett minskat söktryck till de nya yrkesprogrammen gav regeringen i mars 2013 Skolverket i uppdrag att utreda förändringar av kurserna i yrkesprogrammen för att öka elevernas möjligheter att välja kurser som ger grundläggande
} 
På följande sidor ska argumentationen för de allmänna ämnenas närvaro inom yrkesutbildningen undersökas närmare.

\section{Demokrati för samhälle och individ}

Ett första tema som utmärker texterna kan formuleras som demokrati för samhälle och individ. Temat dominerade betänkandet från 1946 års skolkommission. Hela texten syftade till att lägga fram ett "förslag till allmänna riktlinjer för en demokratisering av det svenska skolväsendet" och i skrivningarna betonades att "skolans främsta uppgift blir att fostra demokratiska människor".33 Texten argumenterade mot det vid tiden befintliga skolväsendet, som man menade visade brister när det gällde att förmedla vad samhällsmedborgare behövde. ${ }^{34}$ Istället argumenterade man för att införa en sammanhållen grundskola - enhetsskola - och här blev kravet på en förstärkning av den medborgerliga utbildningen central. Det innebar i realiteten en förlängning av den allmänna obligatoriska skolan och en förskjutning av differentieringen av eleverna högre upp i åldrarna. Orienteringsämnena skulle utformas så att de ökade förståelsen av det samtida samhället och dess problem. Det löstes praktiskt genom att ämnet samhällskunskap infördes och genom att innehållet i ämnen som historia och geografi förändrades. Socialiserande och subjektifierande mål skrevs också fram i de yrkesutbildningssakkunnigas betänkande 1954. Där underströks det att yrkesutbildningen inte fick begränsas till de kunskaper som behövdes för yrkesutövningen, utan att yrkesutbildningen också måste "utveckla karaktären och ge en allmänt medborgerlig bildning, som kan sätta individen i stånd, att bli inte bara en skicklig arbetare utan också en självständig och samarbetsduglig medborgare”. 35

1957 års skolberedning, vars slutbetänkande låg till grund för grundskolebeslutet 1962, fortsatte argumentationen. Skolans medborgarfostrande uppdrag framställdes som ett huvudskäl för att göra den gemensamma undervisningen mer omfattande och längre än tidigare och de allmänbildande inslagen ansågs också vara nödvändiga mål för den utbildning som byggde vidare på grundskolan. Den kvalifikation som allmänbildande ämnen ansågs ge formulerades som en viktig förutsättning för socialisationen i det som betecknades som ett komplicerat samhälle: "Allmänbildningen blir därigenom ett föreningsband som gör det lättare för människor att nå personlig kontakt, utbyta åsikter och samarbeta i de skiftande och invecklade kollektiv, där de lever och verkar". ${ }^{36}$ I ett andra steg i 1960-talets reformarbete fördes gymnasiet, fackskolan och yrkesutbildningen samman i en gemensam skolform och en förberedande yrkesutbildning organiserades i linjer. Inslagen av allmänna ämnen, som begränsades till svenska, gymnastik och arbetslivsorientering samt ett obligatoriskt tillval, motiverades inte uttryckligen med argument om demokratisk fostran av yrkesutbildningsberedningen. 37 Argumentationen för de ökade inslagen skedde istället, vilket redovisas närmare nedan, med hänvisningar till kvalificering och socialisation kopplat till

högskolebehörighet. Detta är från hösten 2013 möjligt, förutsatt att den enskilda skolan utnyttjar möjligheten att erbjuda kurserna.

33 SOU 1948:27, 1-3.

34 SOU 1948:27, 6.

35 SOU 1954:11, 297.

36 SOU 1961:30, 182-83 (citat 183).

37 SOU 1966:3; Prop. 1968:140 (angående riktlinjerna för det fria skolväsendet). 
individens kompetens i arbetslivet, och till individens och samhällets behov av anpassning till en framtida arbetsmarknad.

Efter ÖGY:s utredningsarbete lade den socialdemokratiska regeringen, 1988, fram en proposition om en försöksverksamhet med treåriga yrkesutbildningar på gymnasiet där de allmänbildande inslagen fick större utrymme än vad ÖGY förordat. ${ }^{8}$ I propositionen fanns tydliga spår av ett utvidgat, participatoriskt demokratibegrepp: "Utbildningen skall också ge eleverna goda förutsättningar för att som anställda utöva rätten till medbestämmande". 39 Formuleringen speglade den utveckling av medbestämmande och arbetsplatsdemokrati som pågått i arbetslivet sedan 1970-talet och den kan ses som ett exempel på hur kvalificerings-, socialisations- och subjektifieringsfunktionerna samtidigt finns närvarande. Eleverna ansågs behöva kunskaper, det vill säga kvalificering, för att kunna erövra en position och utöva inflytande inom befintliga strukturer, något som i sin tur förutsatte både socialisation och subjektifiering. År 1991 antog riksdagen den socialdemokratiska regeringens proposition 1990/91:85 om en reform av gymnasieskolan. I den framhölls ett mer direkt samband mellan kunskapsuppbyggnad och demokrati. Individers ökade kunskaper ansågs skapa en vilja "att ha större möjligheter att välja och själva bestämma över sina näraliggande omständligheter”.40 Kärnämneskunskaperna skulle, tillsammans med former för elevinflytande och möjligheter för eleverna att ta ansvar och arbeta självständigt, ge eleverna en bred medborgerlig utbildning, menade man. ${ }^{41}$ Samma förslag lyfte fram betydelsen av en högre naturvetenskaplig allmänbildningsnivå, något som motiverades av en föreställning om ett växande miljöhot och en global resursbrist: "Den nödvändiga miljömedvetenheten förutsätter en naturvetenskaplig alfabetisering som omfattar hela folket, om besluten skall vara gripbara för en demokratisk debatt och för ett demokratiskt beslutsfattande", konstaterades i propositionen. ${ }^{42}$ Det som framhölls var med andra ord den naturvetenskapliga allmänbildningens kvalificerande funktion. Naturvetenskapliga kunskaper hos medborgarna formulerades kort sagt som en förutsättning för samhällets förmåga att hantera de miljöproblem och den resursbrist världen ansågs stå inför. Gemensamma kunskaper för alla elever, utöver dem de fått i grundskolan, beskrevs i det socialdemokratiska förslaget om en ny gymnasieskola 2004 som viktiga för sammanhållningen i samhället, det vill säga socialisation, och för att utveckla en kritisk förmåga hos individerna, med andra ord subjektifiering. ${ }^{43}$ Man föreslog att de tidigare kärnämnena kompletterades med en kurs i historia, som ansågs ge just kunskaper viktiga för förståelsen av samhället och för utvecklandet av ett kritiskt tänkande.44 Den borgerliga regeringens proposition 2009 framförde även den historia som ett obligatoriskt ämne och motiveringen var relativt likartad med den från 2004 (med betoning av ämnets vikt för förståelse av samhällen, kulturer och ideologier). I propositionen 2008/o9:199 menade man att förberedelsen av eleverna

38 ÖGY föreslog en utformning av den gymnasiala yrkesutbildningen som skulle leda till en högre grad av färdigutbildning och högre grad av anknytning till arbetslivet genom praktik jämfört med de yrkeslinjer som konstruerades i linjegymnasiet. Vidare ville man stärka de allmänna ämnena, dock inte i den omfattning som regeringen senare föreslog i sin proposition.

39 Prop 1987/88:102, 36.

40 Prop. 1990/91:85, 42.

41 Prop. 1990/91:85, 99.

42 Prop. 1990/91:85, 44.

43 Prop. 2003/04:140, 28-29, 87.

44 Prop. 2003/04:140, 30-31, 87. 
för medborgarrollen var ett uppdrag som i hög grad vilade på grundskolan. Den borgerliga regeringen gav därmed uttryck för en delvis annan syn på gymnasieskolans ansvar att förmedla allmänna gemensamma kunskaper för att förbereda eleverna som medborgare. 45

I undersökningsperiodens början uttrycktes alltså de allmänna ämnenas socialiseringsfunktion som ett slags demokratisk fostran, något som ansågs så viktigt att det måste beredas plats också inom yrkesutbildningen. Argumentationen skedde med hänvisning till individens känsla av medlemskap i samhällskollektivet, men inte minst till det gemensamma samhällets behov av demokratiskt kompetenta medborgare. Inför yrkesskolans omformning till gymnasiala yrkeslinjer var argumenten för det ökade inslaget av allmänna ämnen tydligare färgade av ekonomiska mål, där de allmänna ämnena ansågs kvalificera eleverna för, och socialisera dem in i, deras framtida yrkesroller. De betraktades också ge eleverna förutsättningar för ett fortsatt lärande. Inför gymnasiereformen 1991 introducerades ett participatoriskt och rättighetsorienterat tema. Med Biestas terminologi kan vi säga att texten tydligare betonade individernas rätt till kunskaper som kvalificerade dem och till arbetsformer som bidrog till deras subjektifiering. Detta ansågs i sin tur betydelsefullt för att de skulle få en reell möjlighet att utöva medbestämmande i arbetslivet. Ett nytt argument var här behovet av naturvetenskaplig allmänbildning för att kunna hantera miljöproblem. 2004 argumenterade man för gemensamma kunskapers socialiserande funktion då man hävdade att de skapade sammanhållning och förståelse mellan de individer som ingick i samhället. Samtidigt betonades subjektifiering genom att behovet av ett kritiskt förhållningssätt bland elever framhölls. Vidare fanns förväntningar om att både socialisation och subjektifiering skulle stärkas genom den kvalificering som det nya inslaget av historieundervisning innebar. Det som tydligast skilde 2009 års proposition från de tidigare texterna var frånvaron av ett tal om gymnasieutbildningens betydelse för en minsta gemensam allmän kunskapsnivå, nödvändig för individernas möjligheter till ett aktivt medborgarskap och för samhällets behov av demokratisk kompetens.

\section{Internationalisering och mångkultur}

Det andra temat rör internationalisering och Sverige som ett mångkulturellt samhälle. De allmänna ämnena ansågs generellt sett, under hela undersökningsperioden, som kvalificerande vad gällde elevernas framtida arbeten i en allt mer internationaliserad ekonomi. Kunskaperna betraktades samtidigt som socialiserande genom att de ökade förståelsen och acceptansen för andra kulturer, såväl inom som utanför Sverige.

1946 års Skolkommission berörde endast i förbigående att det, inom ramen för en höjd allmänbildningsnivå, behövdes viss kunskap om främmande folk och länder för att förstå världshändelser, samt att undervisning i engelska svarade mot ett behov av kunskaper i främmande språk inom yrkes- och organisationslivet. ${ }^{46}$ Vidare argumenterade yrkesutbildningsberedningen 1966 - mot bakgrund av vad som ansågs vara en allt mer internationaliserad ekonomi - för betydelsen av allmänna kunskapsmål för flertalet av eleverna i den framtida yrkesutbildningen. Utökade kontakter med länder

45 Prop. 2008/o9:199, 79, 82.

46 SOU 1948:27, 7. 
och människor i andra delar av världen ansågs medföra ett framtida behov av "kännedom om främmande språk, samhällsförhållanden, religioner m.m.".47 I takt med att samhället blev allt mer mångkulturellt och internationaliserat förändrades dock argumentationen. Medan den tidigare främst hänvisat till de allmänna ämnena som kvalificerande blev socialisationsfunktionen successivt mer framträdande. År 1986 hänvisade exempelvis ÖGY till Sveriges utveckling till ett "flerkulturellt" samhälle, vilket man menade förändrade kraven på skolans undervisning och skapade ett behov av allmänna kunskaper. ${ }^{8}$ Inför reformen 1991 var internationalisering ett av huvudspåren i argumentationen för en breddning av de allmänna ämnena i gymnasieskolan. Kulturen i Sverige ansågs vara på väg att internationaliseras, svenskar reste och vistades i andra länder i allt högre utsträckning och Sverige hade, genom migrationen, blivit ett mångnationellt och mångkulturellt samhälle. Den ökade internationaliseringen motiverade därför en förstärkning av språkutbildningen. Den aktualiserade även behovet av kunskaper om den egna kulturen och historien, vilka betraktades som viktiga även för att förstå andra folk och kulturer. 49

Den första propositionen som föreslog historia som ett obligatoriskt ämne kom från den socialdemokratiska regeringen 2004. I propositionen framhölls då att: "En gemensam kärna av historisk kunskap är angelägen, inte minst i ett mångkulturellt samhälle som vårt, för att visa hur människor skapat och påverkat sina livsbetingelser, samhällen och kulturer samt ge insikt i hur samhällsutvecklingen kan påverkas nationellt och globalt".50 Den efterträdande borgerliga regeringen hävdade på ett likartat sätt i propositionen 2009 att: ”Det är angeläget, inte minst i ett mångkulturellt samhälle som vårt, att förstå hur samhällen, kulturer och olika ideologier har växt fram och hur samhällsutvecklingen kan påverkas nationell och globalt". ${ }^{1}$

Sammanfattningsvis kan konstateras att allmänna ämnen, under 1960-talet, framställdes som kvalificerande för elevernas framtida roller på arbetsmarknaden i en allt mer internationaliserad ekonomi. Under 1980-talet och framåt betonades i större utsträckning de allmänna ämnenas betydelse i ett mångkulturellt samhälle, där de formulerades mot ett mål om socialisering. De allmänna ämnena behövdes för förståelse och tolerans för andra människor i samhället och för en gemensam förståelse av det svenska samhället och kulturen. Trots stora skillnader i övrigt mellan 2004 års och 2009 års propositioner fanns det en samstämmighet i hur man motiverade historieämnets obligatorium, nämligen mot bakgrunden av att Sverige hade blivit ett mångkulturellt samhälle.

\section{Allmänna ämnen för arbetsliv och ekonomisk tillväxt}

Detta tredje tema samlar de argument som hänvisar till utbildningens ekonomiska mål. I analysen blir utbildningens kvalificeringsfunktion särskilt framträdande. Socialisation och subjektifiering genom de allmänna ämnena framstår för den sakens skull inte som oviktiga, men utrymmet för kvalificering är det helt klart dominerande. En tanke som genomgående präglar materialet till och med 2004, är att de allmänna ämnena kvalificerade eleverna i förhållande till deras framtida yrkesutövning och gav

\footnotetext{
47 SOU 1966:3, 148.

48 SOU 1986:2, 145 .

49 Prop. 1990/91:85, 43, 99.

$5^{0}$ Prop. 2003/04:140, 30-31

51 Prop. 2008/o9:199, 82.
} 
dem större möjligheter till såväl fortsatt skolning som omskolning. Därigenom ansågs deras möjligheter att få och behålla ett arbete öka. Det gynnade i sin tur samhället i stort eftersom det gav goda förutsättningar för ett omfattande utbud av kompetent arbetskraft, något som i förlängningen menades bidra till ekonomisk tillväxt. Tanken tecknades mot en bild av ett samhälle och en ekonomi i ständig förändring, samt mot fonden av ett allt mer specialiserat samhälle och arbetsliv.

År 1948 hänvisade Skolkommissionen just till en ökande specialisering i det moderna samhället och 1954 drog de yrkesutbildningssakkunniga slutsatsen att utvecklingen inom samhällsliv och näringsliv ledde till att det inte längre gick att dra en tydlig gräns mellan yrkesutbildning och allmän medborgerlig fostran, och att de fackmässiga studierna därför måste kompletteras med orienterande undervisning om näringsgrenen i stort och om samhället i övrigt. ${ }^{2}$ Inför beslutet om enhetsskolan argumenterade Skolberedningen exempelvis att "ett ytterligare skäl för en förstärkning av den gemensamma grunden i skolans fostran är samhällets och i synnerhet näringslivets starka föränderlighet”. 53 En allt för specialiserad yrkesutbildning ansågs riskera att förlora sitt värde i ett samhälle där stora grupper skulle kunna komma att snabbt behöva byta arbetsuppgifter: "Det är då väsentligt att det finns en god grund av allmänna färdigheter och kunskaper att falla tillbaka på, så att en omskolning kan starta från denna mera tillfredsställande utgångspunkt”, konstaterades det.54 All utbildning, oavsett om den var yrkesinriktad eller allmän, definierades av yrkesutbildningsberedningen 1966 såsom varande inriktad mot produktionslivet. Beredningen menade också att gränsdragningen mellan allmänna och yrkesspecifika kunskaper inte var given och framhöll att målsättningen för all yrkesutbildning var att, förutom att ge kunskaper i yrket, förse eleverna med en grund för framtida fortbildning och omskolning.55 Bredden i utbildningen, med större inslag av allmänna ämnen, var nödvändig med hänsyn till arbetskraftens rörlighet i en produktion som höll på att förändras till följd av tekniska framsteg: ”All utbildning - även den som primärt har allmänbildande och allmänorienterande syfte - blir, sedd som ett led i en utbildningsgång, till sist också direkt eller indirekt ett led i en yrkesutbildning”, fastslog beredningen. ${ }^{6}$ Det vi ser här är en betoning av de allmänna ämnenas kvalificerande funktion i utbildning mot yrkeslivet.

ÖGY fortsatte argumentationen och framhöll att: ”även den utbildning som har allmänbildande och allmänorienterande syfte utgör ett led i yrkesutbildningen direkt eller indirekt; direkt genom att kunskaper och färdigheter erfordras i yrkesutövningen, indirekt genom att mer allmänna kunskaper [...] har betydelse för individen i yrkesrollen”. ${ }^{57}$ På samma sätt som tidigare gjordes också hänvisningar till att ökade inslag av allmänna ämnen minskade risken för att yrkesutbildningar blev återvändsgränder. Enligt direktiven till ÖGY skulle förslagen om den förlängda utbildningen utformas så "att den kan fylla rollen av en första del i ett system av återkommande

\footnotetext{
52 SOU 1948:27, 3; SOU 1954:11, 11, 13, 17. 1954 års betänkande behandlade främst frågan om olika allmänna ämnen i relation till de möjligheter eleverna i 9 y hade vad gällde att gå vidare till olika former av högre utbildning. Texten fokuserade här på individernas behov och möjligheter.

53 SOU 1961:30, 183 .

54 SOU 1961:30, 183 .

55 SOU 1966:3, 20-21, 26, 29.

56 SOU 1966:3, 117.

57 SOU 1986:2, 26.
} 
utbildning”. ${ }^{8}$ ÖGY pekade också på hur ett ökat inslag av allmänna ämnen var viktigt för att bredda rekryteringsbasen till högskoleutbildning. 59 Vidare menade beredningen att utvecklingen av näringslivet var beroende av arbetstagarnas kunskaper, förmåga och möjligheter att medverka i förändringsprocesser. ${ }^{60}$ Kvalificering framhölls med andra ord som en nödvändig förutsättning för individernas medskapande, en förutsättning för socialisation och subjektifiering. Yrkeslivet krävde att arbetstagarna hade kunskaper som kommunikationsförmåga samt kunskaper i språk och matematik för att kunna tillgodogöra sig fackteoretiskt stoff. ${ }^{61}$ Talet om samhällelig och arbetslivsmässig förändring är relativt konstant över en längre tid. I proposition 1987/88:102 återfanns exempelvis i princip samma formulering som i Yrkesutbildningsberedningens betänkande (SOU 1966:3). ${ }^{62}$

I den socialdemokratiska regeringens gymnasieproposition 1990/91:85 Växa med kunskaper framhölls sambandet mellan kunskapsnivå och ekonomisk tillväxt, då man pekade på att länders konkurrenskraft i allt större utsträckning stod i relation till befolkningens utbildningsnivå och innovationsförmåga. "Det mänskliga arbetet blir det strategiska kapitalet i ett kunskapsintensivt näringsliv", hävdade man. ${ }^{63}$ Utökningen av den ämnesteoretiska kärnan inom gymnasieskolan syftade här delvis till att möta arbetslivets krav på goda baskunskaper i både allmänna ämnen och i yrkesämnen. Kunskapsnivån ansågs vara "den viktigaste drivkraften för en fortsatt utveckling av näringslivet och en fortsatt hög sysselsättning”. ${ }^{64}$ Regeringen menade att den utbildning som gavs i gymnasieskolan skulle ses som en etapp i ett livslångt lärande och att det skulle finnas reella möjligheter för elever att gå vidare till högre studier. Kopplingen till universitet och högskolor ansågs inte ha funnits för yrkeslinjernas elever. Istället konstaterades att: "Snarare har många lärare och elever upplevt en motsättning mellan de akademiska traditionerna, som förmedlas genom de allmänna ämnena och de arbetslivsorienterande traditionerna, förmedlade genom yrkesämnena". ${ }^{65}$ Den socialdemokratiska regeringen argumenterade i förslaget för att den högre utbildningen i framtiden även måste kunna rekrytera studenter med yrkesutbildning som grund och att yrkesutbildningens innehåll därför måste breddas. ${ }^{66}$

I betänkandet från ÖGY, i förslaget om försöksverksamhet och i propositionen om 90-talets nya gymnasieskola framträdde allt starkare bilden av en kunskapsbaserad ekonomi. Kvalificeringen av eleverna genom utbildning kunde inte endast omfatta yrkestekniska och yrkespraktiska kunskaper, ansågs det. Den måste också inkludera allmänna kunskapsmål för att stödja sysselsättning och samhällsekonomisk utveckling. Talet om livslångt lärande blev här centralt. Ett större inslag av allmänna ämnen

\footnotetext{
$5^{8}$ SOU 1986:2, 145.

59 SOU 1986:2, 18.

60 SOU 1986:2, 19 .

61 Prop. 1987/88:102, 17.

62 ”[...] de snabba förändringarna i samhälle och arbetsliv medför ökade krav på allmän orientering och på kommunikationsfärdigheter hos den enskilde individen." SOU 1966:3, 148; "Förändringar i samhället och i arbetslivet medför ökade krav på allmän orientering och på kommunikationsfärdigheter hos enskilda individer". Prop. 1987/88:102, 36.

63 Prop. 1990/91:85, 43 .

64 Prop. 1990/91:85, 50 .

65 Prop. 1990/91:85, 50.

66 Prop. 1990/91:85, 50.
} 
för elever i yrkesinriktad utbildning framställdes som viktigare än fördjupning i yrkesutbildningen eftersom de allmänna ämnena antogs ge en bättre grund för lärande längre fram i livet. Argumenten för behovet av en tämligen omfattande kärna av allmänna ämnen fortsatte under senare delen av 1990-talet i förslagen om en utveckling av gymnasieskolan. ${ }^{67}$

I den socialdemokratiska regeringens förslag om en ny gymnasieskola 2004 återkom betoningen av de allmänna ämnena som kvalificerande. Tillsammans med generella yrkeskompetenser framhöll regeringen att goda kunskaper i kärnämnena var "en förutsättning för deltagande i det livslånga och livsvida lärandet. Därmed är de avgörande för att individen skall få och behålla ett arbete under sitt yrkesliv eller att kunna byta verksamhetsområde". ${ }^{68}$ De allmänna ämnenas samhällsekonomiska nytta betonades tydligt i slutet av stycket: "Kärnämnena är därför av central betydelse för sysselsättningen och ett högt arbetskraftsutbud", konstaterades det. ${ }^{69}$ Den tanke som utvecklades i texten, och som fungerade som ett argument för de allmänna ämnenas betydelse, var att de yrkesspecifika kunskaperna i många yrken kunde läras på arbetsplatsen. En grundläggande allmänutbildning ansågs dock vara nödvändig för att arbetsplatsbundet lärande skulle kunna ske effektivt. Därför menade regeringen att breda, generaliserbara och påbyggbara kunskaper skulle betraktas som viktiga för att individerna skulle kunna etablera sig på arbetsmarknaden. ${ }^{70}$ Samtidigt uppmärksammades att många elever på de yrkesinriktade programmen inte nådde målen $\mathrm{i}$ kärnämnena. För att förbättra resultaten skulle undervisningen förändras så att den blev mer relevant för elever med olika bakgrund. Här föreslog man att kärnämnesundervisningen skulle präglas av den utbildning som eleverna gick, bland annat genom samverkan med karaktärsämnena (så kallad infärgning). Däremot skulle mål och kursplaner för ämnena fortsatt vara gemensamma. ${ }^{71}$

I proposition 2008/09:199 framhöll den borgerliga regeringen att: [d]agens kärnämnen ger också kunskaper som behövs i arbetslivet och för fortsatt lärande" ${ }^{72}$ Synen på de allmänna ämnenas betydelse hade dock förändrats jämfört med föregående socialdemokratiska proposition. Istället för förslaget om infärgning för att öka relevansen av kärnämnena (och därmed studieresultaten) för elever i yrkesinriktade program, framhölls att yrkesutbildningarna var för teoretiserade och gymnasieskolan för likformig. Yrkesutbildningen på gymnasiet skulle utformas så att den ledde direkt ut i yrkeslivet eller till fortsatt yrkesutbildning.73 Den borgerliga regeringen menade att för att ge de yrkesspecifika kunskaperna tillräckligt utrymme kunde inte yrkesutbildningen ha ett "alltför omfattande allmänt innehåll”.74 Genomgående var intentionen i reformen av gymnasieskolan att karaktärs- och yrkesämnena skulle utökas, och de gemensamma allmänna ämnena minskas.75 Den gymnasiala

\footnotetext{
67 Prop. 1997/98:169, 16.

68 Prop. 2003/04:140, 62.

69 Prop. 2003/04:140, 62.

70 Prop. 2003/04:140, 85.

${ }^{71}$ Prop. 2003/04:140, 17.

72 Prop. 2008/o9:199, 79.

73 Prop. 2008/o9:199, 37.

74 Prop. 2008/o9:199, 79.

75 Prop. 2008/o9:199, 37.
} 
yrkesutbildningen skulle kort sagt anpassas så att den bättre svarade mot arbetsmarknadens behov. ${ }^{76}$ Den yrkesförberedande gymnasieutbildningens funktion som kvalificerande betonades alltså, men det var framför allt de yrkestekniska och yrkespraktiska inslagen - karaktärsämnena - som ansågs kvalificera eleverna för en framtid på arbetsmarknaden. De hänvisningar som tidigare skett till de allmänna kunskapsmålens betydelse för eleverna i deras yrkesliv och för deras framtid på arbetsmarknaden lyste följaktligen med sin frånvaro. Ett viktigt argument för en utökning av allmänna ämnen var fram till och med 2004 att ett samhälle och en ekonomi som befinner sig i en ständig förändring skapar ett behov av en hög allmän kunskapsnivå bland befolkningen. År 2009 använde man istället bilden av ett samhälle och ett arbetsliv i förändring för att på rakt motsatt sätt motivera en ökad specialisering.

De förändringar som kan urskiljas rörande de allmänna ämnenas kvalificerande funktion för arbetsliv och ekonomi är delvis beroende av i vilken mån man betonar deras betydelse för individ/aktör eller för samhället i stort. För den enskilde handlade det om tillfredställelsen i att ha goda grundläggande kompetenser, i exempelvis kommunikationsförmåga och språk, och att ha förutsättningar att vidareutbilda sig och omskola sig i en föränderlig ekonomi. För samhället handlade det istället om att skapa förutsättningar för långsiktig ekonomisk tillväxt genom att investera i grundläggande utbildning för att därigenom säkerställa ett stort utbud av kompetent arbetskraft. De allmänna ämnena betonades som allt viktigare i takt med att bilden av en kunskapsekonomi växte sig starkare. I propositionen 2009 återfanns istället en föreställning om att förändringarna skulle mötas med en mer specialiserad utbildning. Talet om att allmänna ämnen hade ett bestående värde, och att de därmed var en mer långsiktig och bredare investering i humankapitalet än vad specialiserad utbildning var, hade nu försvunnit. Istället framträdde en syn där yrkesutbildningens funktion ansågs vara att svara mot behov i arbetslivet "just in time", och där de bredare kunskaperna tillskrevs mindre betydelse. Man menade att den form av kvalificering som de allmänna ämnena bidrog till hade för stor plats i läroplanen och att de inte motsvarade arbetsgivarnas behov. Individerna och samhället var kort sagt i större behov av specialisering. Frågan kom således att handla om vilken kvalificering som var viktigast i den yrkesförberedande yrkesutbildningen på gymnasial nivå och här framträdde alltså en skillnad mellan den borgerliga regeringens slutsatser och tidigare socialdemokratiska regeringars.

\section{Förändrade uppfattningar av nyttan med allmänna ämnen}

Utveckling av demokratin, ett internationaliserat och multikulturellt samhälle och en föränderlig och kunskapsintensiv ekonomi betonas i retoriken kring de allmänna ämnena under hela den studerade perioden. Det går dock att diskutera förändringar och kontinuiteter i argumentationen i tydligare relation till brotten år 1968, 1991 och 2009 för att på så vis förtydliga hur vi kan förstå den förändring som skett när det gäller de allmänna ämnenas utrymme inom den yrkesförberedande gymnasieutbildningen. Som analysen visat motiverades utökningen av de allmänna ämnena i grundskolan 1962 främst med hänvisningar till kvalificering och socialisation för att stärka demokratin, och till den kvalificering som behövdes i ett föränderligt näringsliv. Den

\footnotetext{
76 Prop. 2008/o9:199, 39.
} 
stora förändring av yrkesutbildningens former och innehåll som skedde genom 1968 års reformering av det frivilliga skolväsendet låg i linje med detta tänkande och innebar en väsentlig ökning av de allmänna ämnena på bekostnad av yrkestekniska ämnen. De argument som låg bakom denna ökning av de allmänna ämnena grundades på uppfattningen att samhället och arbetsmarknaden snabbt höll på att förändras och att ekonomin internationaliserades allt mer. De allmänna ämnenas kvalificerande och socialiserande funktioner framhölls därför som viktiga för individerna såväl som för samhället.

Genom gymnasiereformen 1991 ökade omfattningen av allmänna ämnen inom den förberedande yrkesutbildningen markant och detta möjliggjordes genom en förlängning av yrkesprogrammen till treåriga utbildningar. En annan viktig aspekt av 1991 års reform var att den medförde gemensamma kurser i ett antal allmänna ämnen för alla gymnasieprogram, oavsett inriktning. I skrivelserna antyddes här ett utvidgat demokratibegrepp som omfattade en förberedelse av individerna till medbestämmande i arbetslivet, en utveckling som dock vidare betraktat pågått i samhället sedan 1970-talet. Analysen visar att subjektifieringsfunktionen här betonades i större utsträckning än tidigare, vid sidan av kvalificering och socialisation. Förutom en utökning av tiden för språk, matematik och samhällsorienterande ämnen tillkom också naturkunskap bland gymnasieskolans kärnämnen. En naturvetenskaplig allmänbildning formulerades i gymnasiereformen 1991 som en nödvändig kvalificering. 77 Den fortsatta internationaliseringen av samhället och ekonomin tillsammans med utvecklingen mot ett mångkulturellt samhälle fördes fram som ytterligare motiv för en utökning av allmänna ämnen. Argumentationen bottnade även i en föreställning om att ekonomin förändrades mot ett ökat kunskapsberoende och att arbetsmarknaden därmed blev mer avancerad och kunskapsintensiv. En bred allmän kunskapsbas sågs vidare som en förutsättning för det livslånga lärande som förväntades bli en oundviklig del av elevernas framtid. 1991 års reform framhöll med andra ord både betydelsen av de allmänna ämnenas kvalificerande, socialiserande och subjektifierande funktioner som betydelsefulla för ekonomin.

År 2009 inträdde en tredje omfattande förändring. Utrymmet för allmänna ämnen minskades då till förmån för en högre grad av specialisering. Hur motiverades det brottet i förhållande till tidigare? Det är uppenbart att gymnasieskolan här gavs en annan betydelse än tidigare, där den tydligare skulle kopplas till den yrkesverksamhet som man förväntade sig att eleverna skulle möta efter avslutad gymnasieutbildning. Detta fick som följd att de allmänna ämnenas betydelse - som kvalificerande, socialiserande och subjektifierande - för individen som medborgare och för att främja en demokratisk samhällsutveckling tonades ned. Förberedelsen för ett aktivt deltagande i samhällslivet formulerades istället som ett uppdrag främst för grundskolan. Historieämnet avvek dock i sammanhanget. I likhet med det tidigare socialdemokratiska förslaget 2004 framhölls i den borgerliga reformen att historieämnet var viktigt för att kvalificera eleverna. De kunskaper som eleverna fick genom historieundervisningen skulle hjälpa dem att förstå det globala såväl som det lokala, och historieämnet förväntades därtill bidra till socialisering i form av sammanhållning och tolerans i det

77 Vid samma tid började man på internationell nivå formulera betydelsen av utbildning och lärande för att möta miljöproblemen. Agenda 21 från Rio-konferensen 1992 ägnar exempelvis ett helt kapitel åt betydelsen av utbildning för att få till stånd en global hållbar utveckling. SOU 2004:104, Att lära för hållbar utveckling, 39. 
mångkulturella samhället. Vidare formulerades det som ett ämne som bidrog till att utveckla elevernas kritiska förmåga och därmed som subjektifierande.

Skrivelserna om yrkesutbildningens innehåll och organisation har genomgående dominerats av motiveringar som hänvisat till arbetsmarknad, produktion och långsiktig ekonomisk tillväxt. Detta är inte helt överraskande med tanke på att yrkesutbildning alltid varit nära förknippad med nytta i bemärkelsen att man talar om kunskaper och färdigheter som ansetts omsättningsbara på en arbetsmarknad och i produktionen av varor och tjänster. Utbildningens kvalificerande funktion - de kunskaper och förmågor som tillåter den som genomgår en utbildning att "göra någonting" - blev i det sammanhanget viktig. Under den period som här har analyserats har argumentationen för vidgade inslag av allmänna ämnen sett relativt likartad ut fram till år 2009. Argumentationen har i stor utsträckning byggt på de allmänna ämnenas konkreta betydelse inom det samhällsekonomiska området. Vidare har de tillskrivits en kvalificerande, socialiserande och med tiden i allt högre grad även en subjektifierande funktion med syftet att utveckla och fördjupa demokratin och sammanhållningen i ett internationaliserat och mångkulturellt samhälle.

Brottet vi ser med 2009 års proposition handlade om vilka former av kvalificering som gymnasieskolan skulle bidra med i den yrkesförberedande utbildningen, vilka kunskaper och förmågor som ansågs vara nyttigast och som därför skulle prioriteras. Här skilde sig den borgerliga reformeringen av gymnasieskolan från de tidigare reformerna som föreslagits av socialdemokratiska regeringar. I analysen har jag visat att argumentationen för den successiva ökningen av allmänna ämnen i den yrkesinriktade utbildningen under efterkrigstiden vilade på tre föreställningar om deras nytta för samhällsutvecklingen: de stödde en fördjupad och utvecklad demokrati, de var viktiga för Sverige i en förvandling till ett mångkulturellt samhälle och de var nödvändiga i en kunskapsintensiv, allt mer internationell och föränderlig ekonomi. Dessa samhällsförhållanden och behov hade givetvis inte upphört 2009. Men den instrumentella syn på utbildning som präglade den borgerliga regeringens utbildningspolitik innbar att man inte alls kopplade samman de allmänna ämnena med arbetsmarknad och ekonomi på samma sätt som föregående reformförslag. 2009 års proposition gav i huvudsak de allmänna ämnena ett demokratiskt syfte, där de i första hand betraktades som viktiga för ett mångkulturellt samhälle. Därtill tonade propositionen ned gymnasieutbildningens allmänna uppgift att förbereda eleverna till ett demokratiskt medborgarskap betydligt, och detta fick sammantaget konsekvensen att de allmänna ämnenas omfattning och betydelse inom yrkesprogrammen kraftigt minskade. Istället framhölls förberedelsen för arbetslivet starkare genom att större utrymme gavs till ett yrkesspecifikt innehåll. De idéer som under hela efterkrigstiden präglat ett samtal om hur de allmänna ämnena kunde verka kvalificerande för elevernas framtida roller på arbetsmarknaden, samt hur den samhällsekonomiska utvecklingen på många sätt var beroende av de generella kunskaper som de allmänna ämnena kunde bidra med, föll i bakgrunden i och med propositionen. Brotten 1968 och 1991 är i detta avseende snarare att betrakta som smärre förskjutningar i betoningen av utbildningsfunktionerna kvalificering, socialisation och subjektifiering. Det stora avsteget vad gäller föreställningarna om de allmänna ämnens samhällsnytta under efterkrigstiden representerades följaktligen av den borgerliga regeringens proposition och dess osynliggörande av de allmänna ämnenas kvalificerande funktion på samhällsekonomiska områden. 


\section{Bilaga 1}

Förändringar av allmänna ämnens andel av den yrkesinriktade utbildningen i gymnasieskolan under perioden 1970-2013: exempel från Bygg- och anläggningsteknisk linje, Byggprogrammet, Bygg- och anläggningsprogrammet. ${ }^{7}$

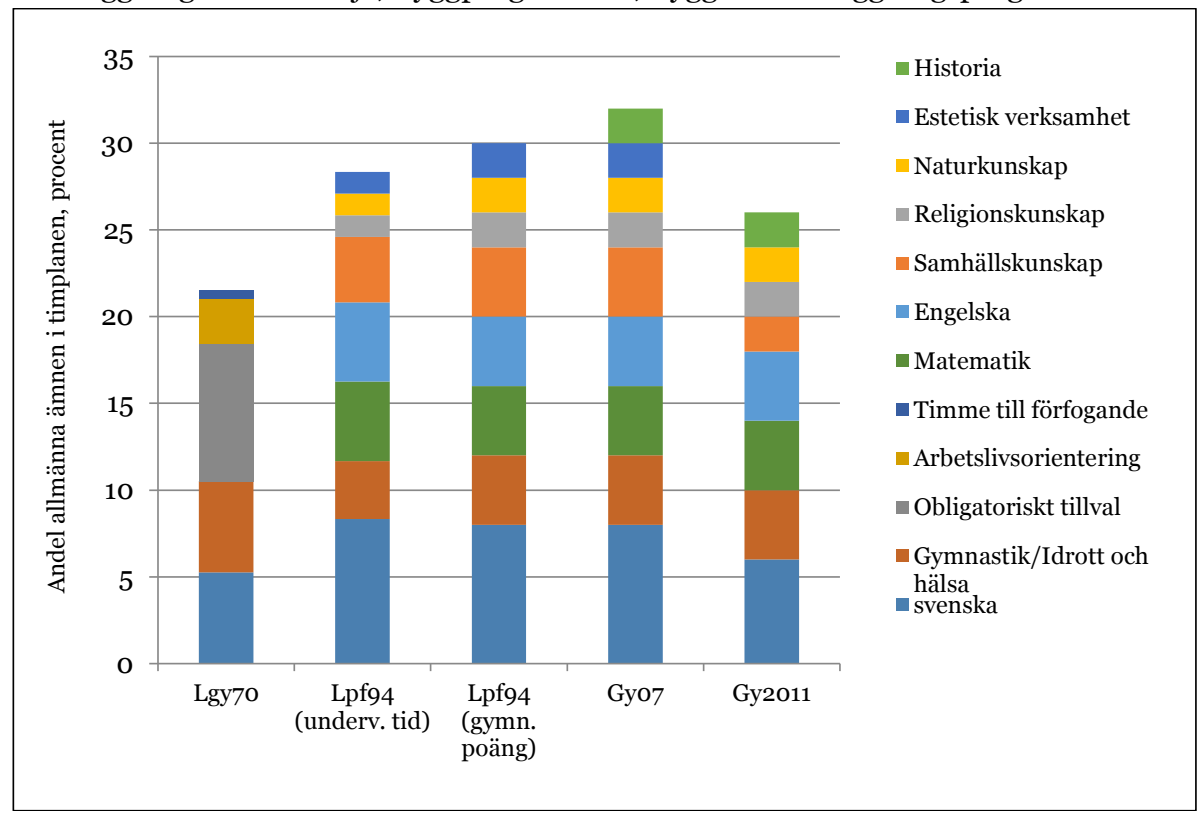

Källor: Lgy 70, Läroplan för gymnasieskolan, Supplement, Tvåårig Bygg- och anläggningsteknisk linje (Stockholm: Skolöverstyrelsen, Liber Utbildningsförlag, 1971), 17; Programmaterial för gymnasieskola och gymnasial vuxenutbildning GyVux 1993:2, Kursplaner -93 (Skolverket, Stockholm: CE Fritzes, Allmänna Förlaget, 1993); Skolverkets författningssamling, SKOLFS 2000:1 (Stockholm: Skolverket, 2000); Prop. 2003/04:140; 10. Läroplan, examensmål och gymnasiegemensamma ämnen för gymnasieskola 2011 (Stockholm: Skolverket, 2011).

\footnotetext{
78 Inom ramen för Lgy 70 varierande allmänna ämnen något mellan olika yrkeslinjer. I och med Lpf 94 och fram till och med Gy 11 är de ämnen som anges del av alla yrkesprogram. Diagrammet redovisar också Prop 2003/04:140 förslag om andel allmänna ämnen i reformen Gy 07, som skrinlades efter regeringsskiftet 2006. I Lgy 70 anges undervisningstiden i veckotimmar. Dessa har räknats om till ett medelvärde för åk 1 och 2. Det obligatoriska tillvalet kunde ske mellan ämnena B- eller C-språk, Religionskunskap, Psykologi, Samhällskunskap, Konsumentkunskap, Matematik, Musik eller teckning. I Lpf 94 angavs minsta garanterade undervisningstid för respektive ämne. Inom de yrkesförberedande programmen var den minsta garanterade undervisningstiden totalt 2400 timmar. I och med övergången till gymnasiepoäng i läroplan och timplaner är det inte möjligt att ange exakt undervisningstid för respektive ämne. Däremot framgår tydligt ämnenas andel av totala gymnasiepoängen i läroplanen. En indikation på gymnasiepoängens motsvarighet till veckotimmar, det vill säga 40 minuters lektioner, görs i not till tabellen i bilaga 2.
} 


\section{Bilaga 2}

\section{Allmänna ämnen i betänkanden och propositioner79}

\begin{tabular}{|c|c|c|}
\hline $\begin{array}{l}\text { Betänkande/ } \\
\text { Proposition }\end{array}$ & Skolform och inriktning & Allmänna ämnen \\
\hline SOU 1948:27 & $\begin{array}{l}\text { Ett förslag om vilka allmänna } \\
\text { ämnen som bör ingå i grund- } \\
\text { skolans årskurs } 9 \text { linje y. }\end{array}$ & $\begin{array}{l}\text { Modersmål, Samhällskunskap och Hälsolära om- } \\
\text { fattande ca } 10 \mathrm{vtm} .{ }^{80}\end{array}$ \\
\hline SOU 1961:31 & $\begin{array}{l}\text { Förslag om allmänna ämnen } \\
\text { i grundskolans årskurs } 9 \\
\text { (linjerna mekanisk, handels, } \\
\text { hushållsteknisk och allmän- } \\
\text { praktisk). }\end{array}$ & $\begin{array}{l}\text { Svenska } 3 \text { vtm, Samhällskunskap } 2 \text { vtm, Geografi } 2 \\
\text { vtm, Biologi 2,5 vtm, Musik/Teckning } 2 \text { vtm, } \\
\text { Gymnastik } 2 \text { vtm. }\end{array}$ \\
\hline Prop. 1968:140 & $\begin{array}{l}\text { Förslag om allmänna ämnen } \\
\text { inom de två-åriga gymna- } \\
\text { siala yrkeslinjerna. }\end{array}$ & $\begin{array}{l}\text { Svenska, Arbetslivsorientering och Gymnastik, obli- } \\
\text { gatoriskt tillval av ett ämne (t.ex. Engelska, Samhälls- } \\
\text { kunskap, Religionskunskap eller Matematik) samt } \\
\text { timme till förfogande. Ex. Mekanisk linje. åk 1: Sven- } \\
\text { ska } 2 \text { vtm, Engelska } 3 \text { vtm, Gymnastik } 2 \text { vtm, åk } 2 \text { : } \\
\text { Svenska } 2 \text { vtm, Samhällskunskap } 2 \text { vtm, Religionskun- } \\
\text { skap } 2 \text { vtm, Arbetslivsorientering } 1 \text { vtm, Gymnastik } 2 \\
\text { vtm. }\end{array}$ \\
\hline Prop. 1991:85 & $\begin{array}{l}\text { Förslag om vilka kärnämnen } \\
\text { som ska ingå i alla } 16 \text { gymna- } \\
\text { sieprogram. }\end{array}$ & $\begin{array}{l}\text { Svenska } 140 \text { timmar (6o min), Engelska 100, Sam- } \\
\text { hällskunskap 80, Matematik 100, Naturkunskap 30, } \\
\text { Idrott och hälsa 80, Estetisk verksamhet 30. } \\
\text { (Religionskunskap tillkommer under ett senare } \\
\text { skede). }\end{array}$ \\
\hline $\begin{array}{c}\text { Prop. } \\
\text { 2003/2004:140 }\end{array}$ & $\begin{array}{l}\text { Förslag om en utökning av } \\
\text { kärnämnena inom gymna- } \\
\text { sieskolan. }\end{array}$ & $\begin{array}{l}\text { Svenska/Svenska som andraspråk } 200 \text { poäng (p), } \\
\text { Engelska } 100 \mathrm{p} \text {, Matematik } 100 \mathrm{p} \text {, Idrott och hälsa } \\
100 \mathrm{p} \text {, Samhällskunskap } 100 \mathrm{p} \text {, Religionskunskap } \\
50 \mathrm{p} \text {, Naturkunskap } 50 \mathrm{p} \text {, Estetisk verksamhet } 50 \text { p, } \\
\text { Historia } 50 \mathrm{p} \text {. }\end{array}$ \\
\hline $\begin{array}{c}\text { Prop. } \\
\text { 2008/o9:199 }\end{array}$ & $\begin{array}{l}\text { Förslag om gymnasiegemen- } \\
\text { samma ämnen för yrkespro- } \\
\text { grammen. }\end{array}$ & $\begin{array}{l}\text { Svenska/Svenska som andraspråk } 150 \text { poäng (p), } \\
\text { Engelska 10op, Matematik 10op, Idrott och hälsa } \\
\text { 10op, Samhällskunskap 50 p, Religionskunskap 50 p, } \\
\text { Naturkunskap 50 p, Historia 50 p. }\end{array}$ \\
\hline
\end{tabular}

Källa: SOU 1948:27; SOU 1961:31; Prop. 1968:140; Prop. 1991:85; Prop. 2003/2004:140; Prop. 2008/09:199

79 Redovisingen av undervisningstiden varierar från angivelse i 40-minuterslektioner fram till klocktimmar i Prop. 1991:85 och slutligen som gymnasiepoäng i de två senaste propositionerna. Gymnasiepoäng motsvarar inte garanterad undervisningstid för enskilda ämnen och kurser. För en ungefärlig jämförelse kan man omvandla 10op till ca 3x40-minuterslektioner per vecka under ett läsår, och en 50 poängskurs 3x40minuterslektioner per vecka under en termin. Omräkning har skett enligt samma princip som använts av Hans Albin Larsson, Barnet kastades ut med badvattnet: Historien om hur skolans historieundervisning närmast blev historia (Bromma: Historielärarnas fören., 2001).

${ }^{80}$ Veckotimmar. 


\section{Referenser}

Arneback, Emma och Andreas Bergh. "Den paketerade valfriheten: Om Framtidsvägen för den svenska gymnasieskolan." Nordisk Pedagogik 30 (2010), 117-31.

Berggren, Jan. "En gemensam resa eller skilda resor: Talet om kärnämnen i gymnasieskolan 1990-2009." Utbildning \& Demokrati 21 (2012), 39-57.

Bergström, Ylva och Ninni Wahlström. "En reformerad gymnasieskola: Med vilka ambitioner?" Utbildning \& Demokrati 17 (2008), 5-16.

Biesta, Gert. "Good Education in an Age of Measurement: On the Need to Reconnect with the Question of Purpose in Education." Educational Assessment, Evaluation and Accountability 21 (2009), 33-46.

Biesta, Gert. God utbildning i mätningens tidevarv. Stockholm: Liber, 2011.

Carlbaum, Sara. Blir du anställningsbar lille/a vän? Diskursiva konstruktioner av framtida medborgare i gymnasiereformer 1971-2011. Umeå: Umeå universitet, 2012.

Carr, Wilfred och Anthony Hartnett. Education and the Struggle for Democracy: The Politics of Educational Ideas. Buckingham: Open University Press, 1996.

Egidius, Henry. Termlexikon i pedagogik, skola och utbildning. Lund: Studentlitteratur, 2006.

Elgström, Ole och Mats Hellstenius. "Curriculum Debate and Policy Change." Journal of Curriculum Studies, 43 (2011), 717-38.

Elgström, Ole och Mats Hellstenius. "How history became a core subject in Swedish upper secondary schools." Scandinavian Journal of Educational Research, 54 (2010), 565-80.

Englund, Tomas. Läroplanens och skolkunskapens politiska dimension. Göteborg: Daidalos, 2005.

Hellstenius, Mats. Kampen om kärnämnet: Om argumentationen för, och synen på, historieundervisningen i gymnasieskolan. Lund: Lunds universitet, 2011.

Larsson, Hans Albin. Barnet kastades ut med badvattnet: Historien om hur skolans historieundervisning närmast blev historia. Bromma: Historielärarnas fören., 2001.

Lgy70, Läroplan för gymnasieskolan, Supplement, Tvåårig Bygg- och anläggningsteknisk linje. Stockholm: Skolöverstyrelsen, Liber Utbildningsförlag, 1971.

Lundahl, Lisbeth, Inger Erixon Arreman, Ulf Lundström och Linda Rönnberg. "Setting Things Right? Swedish Upper Secondary School Reform in a 40-year Perspective." European Journal of Education 45 (2010), 46-59.

Lundahl, Lisbeth. "Skilda framtidsvägar: Perspektiv på det tidiga 2000-talets gymnasiereform." Utbildning \& Demokrati 17 (2008), 29-51.

Lundahl, Lisbeth. Efter svensk modell: LO, SAF och utbildningspolitiken 1944-90. Umeå: Boréa, 1997.

Läroplan, examensmål och gymnasiegemensamma ämnen för gymnasieskola 2011. Stockholm: Skolverket, 2011.

Marklund, Sixten. Skolsverige 1950-1975. D. 1, 1950 års reformbeslut. Stockholm: Liber/Utbildningsförl., 1980.

Marklund, Sixten. Skolsverige 1950-1975. D. 2, Försöksverksamheten. Stockholm: Liber/Utbildningsförl., 1982.

Marklund, Sixten. Skolsverige 1950-1975. D. 4, Differentieringsfrågan. Stockholm: Liber/Utbildningsförl., 1985. 
Nationalencyklopedin."Allmänbildning”.

http://www.ne.se/lang/allm\%C3\%A4nbildning (2014-01-16)

Nilsson, Anders. Visions and Labour Demand: The planning of vocational Education for the Swedish Manufacturing Industry 1950-1993. Lund: Lund Papers in Economic History nr. 39, 1994.

Nilsson, Lennart. Yrkesutbildning i nutidshistoriskt perspektiv: Yrkesutbildningens utveckling från skråväsendets upphörande 1846 till 1980-talet samt tankar om framtida inriktning. Göteborg: Acta Universitatis Gothoburgensis, 1981.

Nylund, Mattias. "Framtidsvägen: Vägen till vilken framtid för eleverna i gymnasieskolans yrkesprogram?” Pedagogisk forskning i Sverige 15 (2010), 33-52.

Nylund, Mattias. Yrkesutbildning, klass och kunskap: En studie om sociala och politiska implikationer av innehållets organisering i yrkesorienterad utbildning med fokus på 2011 års reform. Örebro: Örebro universitet, 2013.

Olofsson, Jonas. "Yrkesutbildning och utbildningspolitik: En inledande översikt." I Yrkesutbildningen $i$ går och $i$ dag: Om tillväxt, välfärd och kön, red. Jonas Olofsson och Ingela Schånberg. Lund: Studentlitteratur, 2000.

Olofsson, Jonas. Svensk yrkesutbildning: Vägval i internationell belysning. Stockholm: SNS förlag, 2005.

Olofsson, Jonas. Krisen i skolan: Utbildning i politiken och i praktiken. Umeå: Borea, 2010.

Olofsson, Jonas och Ingela Schånberg, red. Yrkesutbildningen i går och i dag: Om tillväxt, välfärd och kön. Lund: Studentlitteratur, 2000.

Olofsson, Jonas och Eskil Wadensjö. Ungdomar, utbildning och arbetsmarknad $i$ Norden: Lika men ändå olika. Stockholm: Forskningsrådet för arbetsliv och socialvetenskap (FAS), 2007.

Pettersson, Lars. "Yrkesutbildning för tillväxt." Arbetsmarknad \& Arbetsliv 1 (1997).

Programmaterial för gymnasieskola och gymnasial vuxenutbildning GyVux 1993:2, Kursplaner -93. Stockholm: Skolverket, CE Fritzes, Allmänna Förlaget, 1993.

Prop. 1968:140 (Angående riktlinjerna för det fria skolväsendet).

Prop. 1987/88:102 (Om utveckling av yrkesutbildningen i gymnasieskolan).

Prop. 1990/91:85 (Växa med kunskaper: Om gymnasieskolan och vuxenutbildningen).

Prop. 1997/98:169 (Gymnasieskola i utveckling: Kvalitet och likvärdighet).

Prop. 2003/04:140 (Kunskap och kvalitet: Elva steg för utvecklingen av gymnasieskolan).

Prop. 2008/o9:199 (Högre krav och kvalitet $i$ den nya gymnasieskolan).

Richardson, Gunnar. Svensk utbildningshistoria: Skola och samhälle förr och nu. Lund: Studentlitteratur, 2004.

SKOLFS 2000:1. Skolverkets författningssamling. Stockholm: Skolverket, 2000.

Skolverket. "Sökande och antagna i gymnasieskolan läsåret 2012/13." PM, Dnr 712013:28. http://www.skolverket.se/publikationer?id=2992.

SOU 1948:27. 1946 års skolkommissions betänkande med förslag till riktlinjer för det svenska skolväsendets utveckling.

SOU 1954:11. Yrkesutbildningen: Betänkande.

SOU 1961:30. 1957 års skolberedning. 6, Grundskolan: Betänkande.

SOU 1966:3. Yrkesutbildningsberedningen. 1, Yrkesutbildningen. 
SOU 1986:2. Arbetsgruppen för översyn av den gymnasiala yrkesutbildningen, En treårig yrkesutbildning: Betänkande.

SOU 2004:104. Att lära för hållbar utveckling . 